Research Paper

\title{
Potential Function of Granulysin, Other Related Effector Molecules and Lymphocyte Subsets in Patients with TB and HIV/TB Coinfection
}

Nada Pitabut ${ }^{1}$, Shinsaku Sakurada ${ }^{2}$, Takahiro Tanaka ${ }^{2}$, Chutharut Ridruechai ${ }^{1}$, Junko Tanuma ${ }^{3}$, Takahiro Aoki $^{3}$, Pacharee Kantipong ${ }^{4}$, Surachai Piyaworawong, ${ }^{5}$ Nobuyuki Kobayashi', Panadda Dhepakson ${ }^{7}$, Hideki Yanai ${ }^{8}$, Norio Yamada ${ }^{9}$, Shinichi Oka ${ }^{3}$, Masaji Okada ${ }^{10}$, Srisin Khusmith ${ }^{1}{ }^{\bowtie}$, Naoto Keicho ${ }^{2}$

1. Department of Microbiology and Immunology, Faculty of Tropical Medicine, Mahidol University, Bangkok, Thailand;

2. Department of Respiratory Diseases, Research Institute, National Center for Global Health and Medicine, Tokyo, Japan;

3. AIDS Clinical Center, National Center for Global Health and Medicine, Tokyo, Japan;

4. Department of Medicine, Chiang Rai Regional Hospital, Chiang Rai, Thailand;

5. Mae Chang District Hospital, Chiang Rai, Thailand;

6. Department of Pulmonary Medicine, Center Hospital, National Center for Global Health and Medicine, Tokyo, Japan;

7. Medical Biotechnology Center, National Institute of Health, Department of Medical Science, Ministry of Public Health, Nonthaburi, Thailand;

8. TB/HIV Research Project, Research Institute of Tuberculosis, Japan Anti-Tuberculosis Association, Chiang Rai, Thailand;

9. Research Institute of Tuberculosis, Japan Anti-Tuberculosis Association, Kiyose, Tokyo, Japan;

10. Clinical Research Center, National Hospital Organization, Kinki-Chuo Chest Medical Center, Sakai, Osaka, Japan.

$\triangle$ Corresponding author: Professor Srisin Khusmith, Department of Microbiology and Immunology, Faculty of Tropical Medicine, Mahidol University, 420/6 Rajvithi Road, Bangkok 10400, Thailand. Tel.: +66-2-3549100-13 ext. 1594; Fax: +66-2-6435583, E-mail address: srisin.khu@mahidol.ac.th.

(c) Ivyspring International Publisher. This is an open-access article distributed under the terms of the Creative Commons License (http://creativecommons.org/ licenses/by-nc-nd/3.0/). Reproduction is permitted for personal, noncommercial use, provided that the article is in whole, unmodified, and properly cited.

Received: 2013.04.10; Accepted: 2013.05.30; Published: 2013.06.15

\begin{abstract}
Background: Host effector mechanism against Mycobacterium tuberculosis (Mtb) infection is dependent on innate immune response by macrophages and neutrophils and the alterations in balanced adaptive immunity. Coordinated release of cytolytic effector molecules from NK cells and effector $\mathrm{T}$ cells and the subsequent granule-associated killing of infected cells have been documented; however, their role in clinical tuberculosis (TB) is still controversy.

Objective: To investigate whether circulating granulysin and other effector molecules are associated with the number of $\mathrm{NK}$ cells, $i \mathrm{NKT}$ cells, $\mathrm{VY} 9^{+} \mathrm{V} \delta 2^{+} \mathrm{T}$ cells, $\mathrm{CD} 4^{+} \mathrm{T}$ cells and $\mathrm{CD} 8^{+} \mathrm{T}$ cells, and such association influences the clinical outcome of the disease in patients with pulmonary $T B$ and HIV/TB coinfection.

Methods: Circulating granulysin, perforin, granzyme-B and IFN-y levels were determined by ELISA. The isoforms of granulysin were analyzed by Western blot analysis. The effector cells were analyzed by flow cytometry.

Results: Circulating granulysin and perforin levels in TB patients were lower than healthy controls, whereas the granulysin levels in HIV/TB coinfection were much higher than in any other groups, TB and HIV with or without receiving HAART, which corresponded to the number of $\mathrm{CD8}^{+} \mathrm{T}$ cells which kept high, but not with NK cells and other possible cellular sources of granulysin. In addition, the $17 \mathrm{kDa}, 15 \mathrm{kDa}$ and $9 \mathrm{kDa}$ isoforms of granulysin were recognized in plasma of HIV/TB coinfection. Increased granulysin and decreased IFN-Y levels in HIV/TB coinfection and TB after completion of anti-TB therapy were observed.
\end{abstract}


Conclusion: The results suggested that the alteration of circulating granulysin has potential function in host immune response against TB and HIV/TB coinfection. This is the first demonstration so far of granulysin in HIV/TB coinfection.

Key words: Granulysin, TB, HIV, HIV/TB Coinfection, Lymphocytes Subsets.

\section{Introduction}

Tuberculosis (TB) is the leading cause of death in human immunodeficiency virus (HIV)-infected individuals in countries with the highest TB burden [1]. Coinfection with HIV evidently affects the progression of Mycobacterium tuberculosis $(M t b)$ infection and induces $M t b$-specific immune responses contributing to increased HIV replication through cellular activation $[2,3]$. It is clear that the overall disruption of immune function in HIV infected patients is the sum of multiple factors including $\mathrm{CD} 4^{+} \mathrm{T}$ cell depletion by direct infection of HIV-1 and chronic immune activation leading to dysfunction of the immune system [4]. Pathologically HIV/TB coinfection caused functional disruption of local immune responses leading to weakened granulomatous host response to $M t b$ [5]. However, immune activation induced by rapid reactivation of $M t b$ in chronic HIV infection has not been fully investigated to our knowledge.

Granulysin is a member of the saposin-like protein family and co-localizes in the granular compartments of human natural killer (NK) cells, double negative invariant NKT ( $i$ NKT), Vgamma $(\gamma) 9^{+}$Vdelta

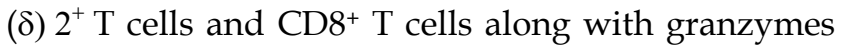
and perforin [6]. It is a cationic small glycoprotein and synthesized as a secretary $15 \mathrm{kDa}$ precursor which is then enzymatically processed into a granular $9 \mathrm{kDa}$ protein. The $9 \mathrm{kDa}$ isoform has characteristics of proinflammatory cytokine and cytolytic activity [7], which is able to induce cytolysis of various tumor cells, microbe-infected cells by release into the intercellular space between target and effector cells via granule exocytosis pathway upon stimulation [8] and mediates killing of extracellular and intracellular $M t b$ [9] via several effector molecules including perforin and granzymes. In contrast, the $15 \mathrm{kDa}$ granulysin is constitutively secreted from NK and $\mathrm{T}$ cells via non-exocytotic pathway [10]. The $\mathrm{CD}^{+} \mathrm{T}, \mathrm{NK}$ and even $\mathrm{CD}^{+} \mathrm{T}$ cells can express granulysin together with perforin and granzyme B co-localized in granules [11] and released into immunological synapse upon activation [12]. Granulysin-mediated lysis of $M t b$ infected cells has been performed mainly by $\mathrm{CD}^{+}$and NKT cells expressing perforin and granulysin $[9,13,14]$. High frequency of $\mathrm{CD}^{+} \mathrm{T}$ cells coexpressing granulysin was observed in children and adolescents [15]. Moreover, $i$ NKT cells exhibiting an- timycobacterial activity also expressed granulysin against $M t b$ inside monocytes/macrophages [14]. In addition, a reduced number of $i$ NKT cells in peripheral blood were found in patients with pulmonary TB and HIV-1 infection [16]. In TB, granulysin and perforin could be detected in $\mathrm{V}_{\gamma} 9^{+} \mathrm{V} \delta 2^{+} \mathrm{T}$ cells, indicating their direct contribution to a protective host response against $M t b$ infection [17].

Reduction of perforin and granulysin levels related to granzyme A has been reported in lung tissue biopsy from patients with chronic $\mathrm{TB}$, while higher expression in $\mathrm{CD}^{+} \mathrm{T}$ cells was associated with bacteriological control, suggesting that perforin and granulysin could be used for evaluation of immune protection in human TB [18]. The primary effector function of $\mathrm{CD}^{+} \mathrm{T}$ cells is believed to be the production of interferon-gamma (IFN)- $\gamma$ and other cytokines to activate macrophages, which can then control or eliminate intracellular organisms [19]. It has been shown that $\mathrm{CD} 4^{+} \mathrm{T}$ cells were the main sources of IFN- $\gamma$ and the relative responses to early secreted antigenic target (ESAT)-6 and culture filtrate protein (CFP)-10 significantly increased in even chronically HIV-infected patients with decreased $\mathrm{CD} 4{ }^{+} \mathrm{T}$ cells, whereas acute HIV infection induced a rapid depletion of $M t b$-specific $\mathrm{CD}^{+} \mathrm{T}$ cells in asymptomatic TB $[20,21]$. In active pulmonary TB, high circulating IFN- $\gamma$ level was detected which decreased significantly after two months of therapy $[22,23]$. Similar results were found in child TB patients [24]. These indicate the involvement of IFN- $\gamma$ in curative immune response against $M t b$.

Significantly lower plasma granulysin levels than controls have been demonstrated in adults with active pulmonary TB in highly $\mathrm{TB}$ endemic area in Indonesia which increased after two months of anti-TB therapy, reaching the values similar to those of controls and even further increased after completion of anti-TB therapy. Such granulysin levels were predominantly in patients expressed by IFN $-\gamma$ negative T cells suggesting that their cellular source of IFN- $\gamma$ and granulysin in TB are partly non-overlapping [12]. Patients with active pulmonary TB had low circulating granulysin but high IFN- $\gamma$ levels, indicating their possible role in host defense against $M t b$ [25]. Earlier study demonstrated that higher plasma IFN- $\gamma$ was 
found in patients with HIV/TB coinfection than TB [26], suggesting a greater degree of immune activation in HIV/TB coinfection, particularly those with low $\mathrm{CD} 4^{+} \mathrm{T}$ cells counts.

There is limited information so far regarding the role of granulysin and other cytolytic effector molecules related to NK cells, $i$ NKT cells, T cells and their subpopulations against $M t b$ infection in $\mathrm{TB}$ and HIV/TB coinfection. This study aims to investigate whether circulating granulysin and other effector molecules are associated with the number of corresponding functional cells, NK cells, $i$ NKT cells, $\mathrm{V} 9^{+} \mathrm{V} \delta 2^{+} \mathrm{T}$ cells, $\mathrm{CD} 44^{+} \mathrm{T}$ cells and $\mathrm{CD} 8^{+} \mathrm{T}$ cells, and such association may influence the clinical outcome of the disease in patients with pulmonary $\mathrm{TB}$ and HIV/TB coinfection in northern Thailand where TB is endemic.

\section{Materials and Methods}

\section{Study subjects}

Six patients with HIV/TB coinfection and $21 \mathrm{~TB}$ patients were recruited from the outpatient and inpatient clinics of Chiang Rai Hospital and Mae Chan Hospital, north of Thailand. Pulmonary TB patients were categorized based on WHO criteria (WHO, 2009), defining whether or not the patients has previously received $\mathrm{TB}$ treatment. TB drug regimens were based on the recommendation of National Tuberculosis Program, Ministry of Public Health,Thailand. The patients with HIV/TB coinfection and TB were all newly diagnosed TB confirmed by microscopic examination of acid-fast bacilli (AFB) in sputum and positive cultures of $M t b$, medical his- tory and chest radiographic findings. All had never received any anti-TB therapy or taken anti-TB drugs for less than 7 days and never received any antiretroviral therapy, immune-suppressive drugs or other immunomodulators prior enrollment. None had diabetes mellitus or other acute infections. The patients with HIV/TB coinfection had not previously received highly active antiretroviral therapy (HAART), the standard drug treatment, and were positive for anti-HIV antibody by the particle agglutination assay (Serodia-HIV-1/2, Fujirebio Inc, Tokyo, Japan) and enzyme-linked immunosorbent assay (ELISA) (Enzygnost Anti-HIV 1/2 plus ELISA, or immunochromatographic rapid test (Determine HIV-1/2, Abbott Laboratories, Ill, USA) Dade Behring, Marburg, Germany). No patients were reported to be multidrug resistance (MDR) or extensively drug resistance (XDR) cases by drugs sensitivity tests at the time of enrollment. Eleven patients with HIV without receiving HAART (HIV+HAART-) and 17 with HIV receiving HAART (HIV+HAART+) were recruited from the HIV Care and Treatment Project (Daycare clinic). These patients had no previous TB episodes and had not received isoniazid preventive therapy (IPT) to sterilize latent TB infection (LTBI) and prevent progression to active TB at the time of enrollment. Their sputum smears were negative for AFB and $M t b$ cultures. They were negative (induration $<5$ $\mathrm{mm}$ ) by Tuberculin Skin Test (TST) and had no concomitant active AIDS-related opportunistic infections within 30 days prior enrollment. The clinical characteristics of individual HIV/TB coinfection are summarized in Table 1.

Table I. Clinical characteristics of patients with HIV/TB coinfection.

\begin{tabular}{|c|c|c|c|c|c|c|}
\hline Characteristic & Patient 1 & Patient 2 & Patient 3 & Patient 4 & Patient 5 & Patient 6 \\
\hline Sex/Age & Male/42 & Male/47 & Male/44 & Female/46 & Male/30 & Male/37 \\
\hline CXR findings at TB diagnosis & Non-cavitary & $\begin{array}{l}\text { Non-cavitary, } \\
\text { infiltrates, pleu- } \\
\text { ral effusion }\end{array}$ & Cavitary & Non-cavitary & Non-cavitary & $\begin{array}{l}\text { Non-cavitary, } \\
\text { pleural effu- } \\
\text { sion }\end{array}$ \\
\hline Presenting form of $\mathrm{TB}$ & Pulmonary & $\begin{array}{l}\text { Pulmonary + } \\
\text { extra-pulmonary } \\
\text { (meningeal) }\end{array}$ & Pulmonary & $\begin{array}{l}\text { Pulmonary }+ \\
\text { extra-pulmonary } \\
\text { (colitis) }\end{array}$ & $\begin{array}{l}\text { Pulmonary }+ \\
\text { extra-pulmonary } \\
\text { (lymp node) }\end{array}$ & Pulmonary \\
\hline Treatment regimen for TB & 2HRZE/4HR & 2HRZE/4HR & 2HRZE/4HR & 2HRZE/4HR & 2HRZE/4HR & 2HEOS/18HE \\
\hline $\begin{array}{l}\text { HAART initiation during study } \\
\text { period }^{*}(\text { regimen) }\end{array}$ & $\begin{array}{l}\text { Yes } \\
\text { (d4T,3TC,NVP) }\end{array}$ & No & No & No & No & $\begin{array}{l}\text { Yes } \\
\text { (d4T,3TC,EFV) }\end{array}$ \\
\hline $\begin{array}{l}\text { Outcomes after } 6-9 \text { mo of anti-TB } \\
\text { therapy } \\
\text { Duration of TB treatment (month) }\end{array}$ & $\begin{array}{l}\text { Cured } \\
7\end{array}$ & $\begin{array}{l}\text { Cured } \\
6\end{array}$ & $\begin{array}{l}\text { Cured } \\
8\end{array}$ & ${ }_{-} \mathrm{N} / \mathrm{A}^{* *}$ & $\begin{array}{l}\mathrm{N} / \mathrm{A}^{* *} \\
-\end{array}$ & $\begin{array}{l}\text { Cured } \\
18\end{array}$ \\
\hline
\end{tabular}

$\mathrm{d} 4 \mathrm{~T}$ = Stavudine; $3 \mathrm{TC}=$ Lamivudine; $\mathrm{NVP}=$ Nevirapine; $\mathrm{EFV}=$ Efavirenz; HAART = highly active antiretroviral therapy. ${ }^{*}$ HAART initiated 2 months after starting anti-TB treatment. ${ }^{* *}$ Unable to follow-up. 
Twenty three healthy individuals recruited from Blood Bank of Mae Chan hospital was used as controls. They had no history of TB and no risk factors involving TB and their chest radiographs were normal. None of them had diabetes mellitus and all were negative for Hepatitis B surface antigen, Hepatitis C antigen and anti-HIV antibody.

This study was approved by the Ethical Review Committee for Research in Human Subjects, Ministry of Public Health, Thailand and the National Center for Global Health and Medicine, Japan, and the written informed consents were obtained from all patients and all healthy individuals.

\section{Blood samples}

Blood were collected in $\mathrm{K}_{3}$ EDTA vacutainers upon enrollment $(n=6$ for HIV/TB coinfection and 21 for TB) and after completion of anti-TB therapy for 6-9 months when they were considered as cured ( $\mathrm{n}=3$ for $\mathrm{HIV} / \mathrm{TB}$ coinfection and 13 for TB). Plasma were separated by centrifugation and stored at $-80^{\circ} \mathrm{C}$.

\section{Determination of granulysin concentration}

The granulysin concentrations in plasma were determined by ELISA [25]. The test was done in duplicate. Briefly, a microtiter plate (Costar, USA) was coated with $100 \mu \mathrm{l} /$ well containing $5 \mu \mathrm{g} / \mathrm{ml}$ mouse monoclonal anti-human granulysin (RB1) (MBL International Corporation, Nagoya, Japan) in $0.05 \mathrm{M}$ carbonate-bicarbonate buffer ( $\mathrm{pH} 9.5$ ) and incubated overnight at $4^{\circ} \mathrm{C}$. The plates were washed with phosphate buffered saline (PBS) containing 0.05\% Tween 20 and blocked with buffered protein solution with ProClin-150 at room temperature (RT) for $1 \mathrm{~h}$. After being washed, the undiluted plasma was added and incubated for $2 \mathrm{~h}$ at RT and followed by washing. The bound antigens were detected with $0.1 \mu \mathrm{g} / \mathrm{ml}$ of mouse monoclonal anti-human granulysin biotin (RC8) (MBL International Corporation) and avidin-horseradish peroxidase (Av-HRP) conjugate (BD Biosciences Phamingen, San Diego, CA) diluted to 1:1000. After incubation for $1 \mathrm{~h}$, the reactions were developed by coloring with tetramethylbenzidine (TMB) substrate (BD Biosciences Phamingen) for 20 min in the dark. Optical densities were measured at $450 / 570 \mathrm{~nm}$ wave-length by a microplate reader (Sunrise; Tecan, Männedorf, Switzerland). The granulysin concentrations were calculated from the standard curve using granulysin in culture supernatant from Cos7 cell transfected with gene encoding 15 $\mathrm{kDa}$ granulysin. The lower detection limit for granulysin is $0.047 \mathrm{ng} / \mathrm{ml}$.

\section{Determination of perforin, granzyme B and IFN- $\gamma$}

ELISA was used to determine the concentration of plasma perforin and granzyme B (MABTECH AB, Sweden), and IFN-ץ (BD Biosciences Phamingen, San Diego, USA) according to the manufacture protocols. The test was done in duplicate. The detection limits of perforin, granzyme B and IFN- $\gamma$ assays were $78,8.78$ and $4.7 \mathrm{pg} / \mathrm{ml}$, respectively.

\section{Western blot analysis}

The isoforms of granulysin with different molecular weight were analyzed by Western blot in 3 patients with $\mathrm{HIV} / \mathrm{TB}$ coinfection and 3 with TB whose plasma were enough to be tested and one healthy controls (HC). The concentration of proteins with low molecular weight was performed by differential solublilization (DS)-method prior to SDS-PAGE and blotting [27]. Briefly, $36 \mu \mathrm{l}$ of $7 \mathrm{M}$ urea/2M thiourea and $4 \mu \mathrm{l}$ of $200 \mathrm{mM}$ DTT were added to $20 \mu \mathrm{l}$ of plasma and then mixed. The solution was dropped into $1.8 \mathrm{ml}$ of purified acetone at $4^{\circ} \mathrm{C}$ with stirring and centrifuged at $19000 \times \mathrm{g}$ at $4^{\circ} \mathrm{C}$ for $15 \mathrm{~min}$. Four hundred $\mu \mathrm{l}$ of $70 \%$ acetonitrile/ $12 \mathrm{mM}$ HCL were added to pellet and stirred at $4^{\circ} \mathrm{C}$ for $1 \mathrm{~h}$. The solution was centrifuged at $19000 \times \mathrm{g}$ at $4^{\circ} \mathrm{C}$ for $15 \mathrm{~min}$. The collected supernatant was subsequently dried by centrifugal concentrator (TAITEC, Koshigaya, Japan) and dissolved in $80 \mu \mathrm{l}$ of $0.1 \%$ trifuluoroacetic acid. Equal volume of each sample was analyzed by SDS-PAGE, transferred onto $0.2 \mu \mathrm{m}$ pore-size PVDF membrane (GE Healthcare, Buckinghamshire, UK) and then blotted with goat anti-granulysin polyclonal antibody (R\&D, USA). Immunodetection was performed by incubation with HRP conjugated with rabbit anti-goat IgG (1:10000) (Cappel, MP Biomedicals, USA) and developed by ECL-prime detection reagents (GE Healthcare, USA).

\section{Flow cytometric analysis}

Peripheral blood mononuclear cells (PBMCs) were isolated by a Ficoll-metrizonate density gradient centrifugation (Lymphoprep ${ }^{\mathrm{TM}}$ tube, AXIS-SHIELD PoC AS, Oslo, Norway) and suspended in cold 10\% FBS in RPMI 1640 medium (Gibco, Invitrogen, USA). In this study, the monocytes depleted PBMCs were used instead of PBMCs due to the need of monocytes in the separation study. To remove monocytes, PBMCs were re-suspended in cold separation buffer, incubated with microbeads conjugated to mouse anti-human CD14 monoclonal antibody (Miltenyi Biotec, Germany) and passed through a magnetic cell separation system (MACS, Miltenyi Biotech) on LS 
column. The viability of the cells determined by Trypan blue exclusion was $\geq 95 \%$.

To determine the surface markers of NK cells $\left(\mathrm{CD} 56^{+} \mathrm{CD}^{-}\right), i \mathrm{NKT}$ cells $\left(\mathrm{Va} 24^{+} \mathrm{CD}^{+}\right)$, $\gamma \delta \mathrm{T}$ cells

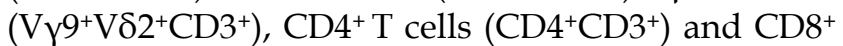
$\mathrm{T}$ cells $\left(\mathrm{CD}^{+} \mathrm{CD}^{+}\right)$, the monocyte depleted PBMC were directly stained with a combination of fluorochrome-conjugated monoclonal antibodies (IMMUNOTECH, Beckman Coulter Company, France) for $30 \mathrm{~min}$ at $4^{\circ} \mathrm{C}$ in the dark and determined by flow cytometry using four-color immunofluorescent technique. Briefly, different cell populations were determined in $1 \times 10^{6}$ monocyte depleted PBMCs per tube using the specific antibodies conjugated to fluorescein isothiocyanate (FITC), phycoerythrin (PE), phycoerythrin-Texas Red-x (ECD) and phycoerythrin-cyanin5 (PC5) (IMMUNOTECH, Beckman Coulter Company, France) as follows: tube no. 1, FITC-labeled anti-Vy9 (clone IMMU 360), PE-labeled anti-Va24 (clone C15), ECD-labeled anti-CD3 (clone UCHT1) and PC5-labeled anti-CD8 (clone B9.11); tube no. 2, FITC-labeled anti-V82 (clone IMMU389), PE-labeled anti-CD56 (clone N901), ECD-labeled anti-CD3 (clone UCHT1), and PC5-labeled anti-CD4 (clone 13B8.2). Mouse isotype IgG1-FITC (clone 679.1 Mc7), IgG1-PE (clone 679.1 Mc7), IgG1-ECD (clone 679.1 Mc7), and IgG1-PC5 (clone 679.1 Mc7) (IMMUNOTECH, Beckman Coulter Company, France) were used as isotype controls. After incubation, the erythrocytes were lysed with $500 \mu \mathrm{l}$ of optilyse C lysis solution (Beckman Coulter, France) and incubated for $10 \mathrm{~min}$ at $4^{\circ} \mathrm{C}$ in the dark followed by adding $500 \mu \mathrm{l}$ of PBS. The solutions were processed for flow cytometric analysis by four color detection EPICS $^{\circledR}$ XL $^{\text {TM }}$ Flow cytometer (Beckman Coulter, Japan) and the data were analyzed using the $\mathrm{XL}$ SYSTEM IITM software. Data were displayed as four-color dot plots.

\section{Statistical analyses}

The data were analyzed using SPSS software version 18.0 (SPSS, Inc., Chicago, IL). The concentrations of granulysin, perforin, granzyme-B and IFN- $\gamma$ in plasma and the surface markers expression on effector cells in each subject group were shown by median and interquartile range. Significant difference between two independent subject groups was compared by Mann-Whitney U test. Wilcoxon Signed Rank test was used to compare plasma granulysin and IFN- $\gamma$ levels before and after completion of anti-TB therapy. The correlations among circulating granulysin, perforin, granzyme-B, IFN- $\gamma$ and the number of NK cells, $i \mathrm{NKT}$ cells, $\mathrm{V}_{\gamma} 9^{+} \mathrm{V} \delta 2^{+} \mathrm{T}$ cells,
$\mathrm{CD}^{+} \mathrm{T}$ and $\mathrm{CD}^{+} \mathrm{T}$ cells were analyzed using a Spearman's rank correlation test. $\mathrm{P}$ value $<0.05$ was considered as statistical significance.

\section{Results}

\section{High granulysin and IFN-Y in HIV/TB, but low granulysin and perforin levels in TB}

The comparison of circulating granulysin, perforin and granzyme-B among patients with HIV/TB coinfection, TB, HIV+HAART- and HIV+HAART+ were shown in Figure 1 and Table 2. HIV/TB patients had significantly higher granulysin (median $=5.556$ $\mathrm{ng} / \mathrm{ml}$, ranged 1.744-12.718) than TB patients (median $=0.905 \mathrm{ng} / \mathrm{ml}$, ranged 0.735-1.272) $(\mathrm{p}=0.001)$ and healthy controls $(\mathrm{HC})$ (median $=1.322 \mathrm{ng} / \mathrm{ml}$, ranged $0.873-1.591)(p=0.012)($ Fig.1A), while TB patients had significantly lower than those of HC ( $p=0.003)$.

No significance difference in perforin levels was found in HIV $/ \mathrm{TB}$ coinfection (median $=9418 \mathrm{pg} / \mathrm{ml}$, ranged 4328-11386) and HC (median $=10363 \mathrm{pg} / \mathrm{ml}$, ranged 7388-13430), while the levels in $\mathrm{TB}$ (median = $5538 \mathrm{pg} / \mathrm{ml}$, ranged 4749-7519) were significantly lower than HC ( $p<0.001)$ (Figure 1B). All study groups had granzyme-B levels as detection limit (Figure 1C). On average, IFN-ץ levels were obviously higher in HIV $/ \mathrm{TB}$ (median $=33.30 \mathrm{pg} / \mathrm{ml}$, ranged 6.215-111.295) than TB patients (median $=11.08$ $\mathrm{pg} / \mathrm{ml}$, ranged $<4.7-25.43$ ) ( $\mathrm{p}<0.001)$, and HC (median $<4.7 \mathrm{pg} / \mathrm{ml}$, ranged $<4.7-15.09)(\mathrm{p}<0.001)$, respectively (Figure 1D).

\section{Three different isoforms of circulating gran- ulysin in patients with HIV/TB coinfection}

When the granulysin were analyzed by DS-method and Western blot analysis, three bands were detected corresponding to isoforms with molecular weight of $17 \mathrm{kDa}, 15 \mathrm{kDa}$ and $9 \mathrm{kDa}$ in plasma of patients with HIV/TB coinfection (Figure 2).

\section{Small number of $i N K T$ cells, $V y 9+V \delta 2+T$ cells and $\mathrm{CD4}^{+} \mathrm{T}$ cells but high number of $\mathrm{CD8}^{+} \mathrm{T}$ cells in HIV/TB coinfection}

Compared to $\mathrm{TB}$, the number of $i \mathrm{NKT}$ cells, $\mathrm{V} 9^{+} \mathrm{V} \delta 2^{+} \mathrm{T}$ cells and $\mathrm{CD} 4^{+} \mathrm{T}$ cells was small but the number of $\mathrm{CD}^{+} \mathrm{T}$ cells was kept high in HIV/TB coinfection as shown in Figure 3 and individual data of HIV/TB patients in Table 2. Significantly higher number of NK cells in patients with $\mathrm{TB}$ (median = 1936 cells/ $\mu$ l, ranged 2016-2634) than HIV/TB patients $(\mathrm{HIV} / \mathrm{TB}$, median $=787$ cells $/ \mu \mathrm{l}$, ranged 321-1303, $\mathrm{p}=0.031)$ was observed. 
Table 2. Levels of circulating granulysin, perforin, granzyme-B and IFN-Y and number of effector cells in patients with HIV/TB coinfection before anti-TB therapy.

\begin{tabular}{lllllll}
\hline Characteristic & Patient 1 & Patient 2 & Patient 3 & Patient 4 & Patient 5 & Patient 6 \\
\hline Granulysin $(\mathrm{ng} / \mathrm{ml})$ & 3.746 & 7.365 & 9.841 & 1.313 & 21.35 & 1.887 \\
Perforin $(\mathrm{pg} / \mathrm{ml})$ & 10763 & 10305 & 13255 & 8530 & 1722 & 5197 \\
Granzyme-B $(\mathrm{pg} / \mathrm{ml})$ & 41.33 & $<8.79$ & 26 & $<8.79$ & $<8.79$ & $<8.79$ \\
$\mathrm{IFN}-\gamma(\mathrm{pg} / \mathrm{ml})$ & 89.54 & 53.04 & 6.72 & $<4.7$ & 13.56 & 176.56 \\
$\mathrm{NK}$ cells $($ cells $/ \mu \mathrm{l})$ & 646 & 991 & 2239 & 346 & 244 & 1 \\
$i \mathrm{NKT}$ cells $($ cells $/ \mu \mathrm{l})$ & 8 & 2 & 4 & 2 & 528 & 1 \\
$\mathrm{~V} \gamma^{+} \mathrm{V} \delta 2^{+} \mathrm{T}$ cells $(\mathrm{cells} / \mu \mathrm{l})$ & 44 & 7 & 6 & 321 & 94 & 3 \\
$\mathrm{CD} 4^{+} \mathrm{T}$ cells $($ cells $/ \mu \mathrm{l})$ & 46 & 198 & 344 & 606 & 181 & 19 \\
$\mathrm{CD} 8+\mathrm{T}$ cells $($ cells $/ \mu \mathrm{l})$ & 854 & 2068 & 1309 & & 168 \\
\hline
\end{tabular}

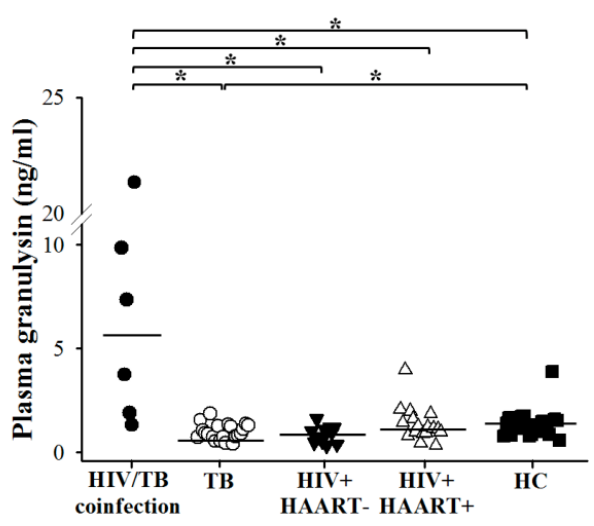

A
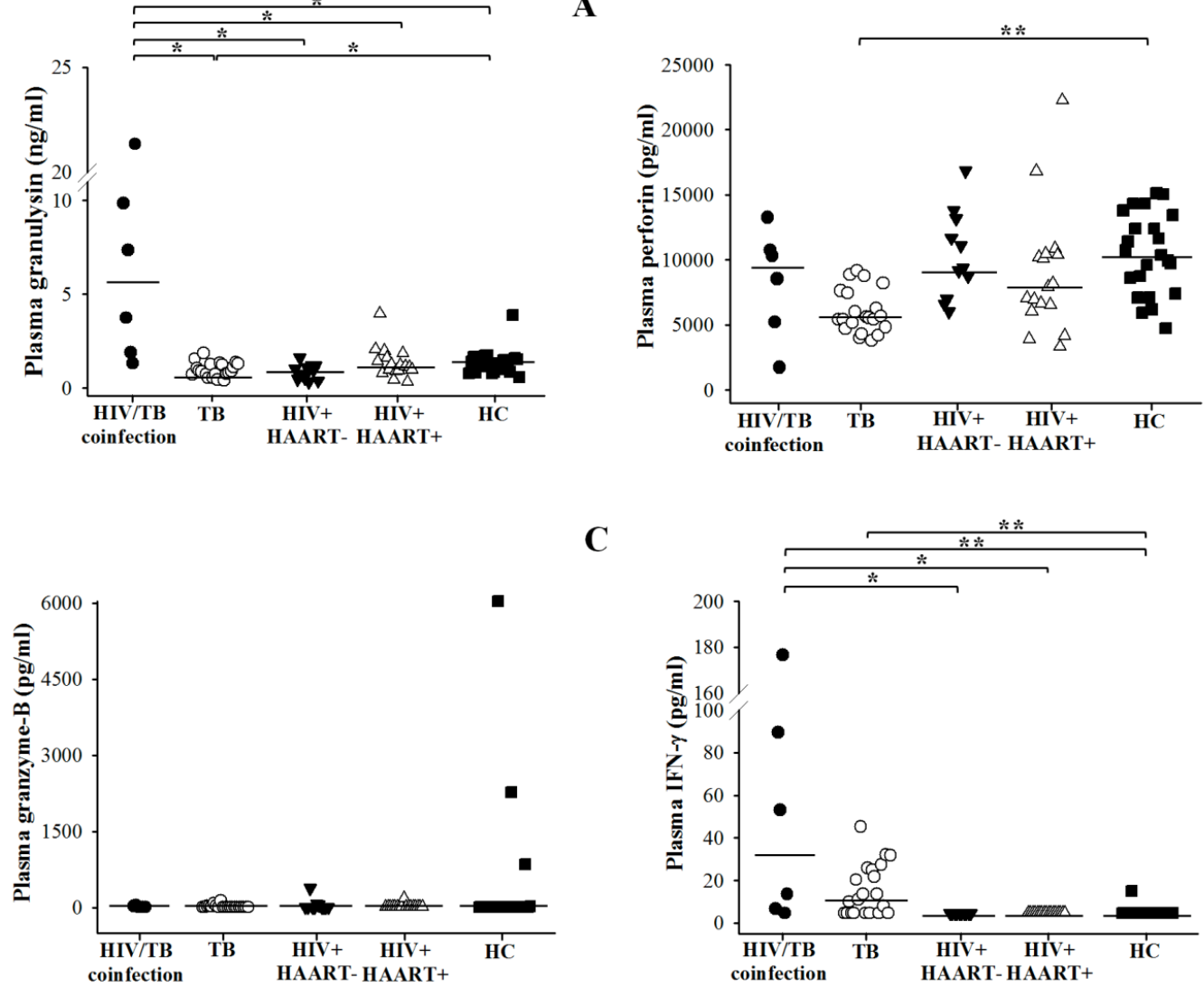

Fig I. Circulating granulysin $(\mathrm{ng} / \mathrm{ml})(A)$, perforin $(\mathrm{pg} / \mathrm{ml})(B)$, granzyme-B $(\mathrm{pg} / \mathrm{ml})(\mathrm{C})$ and IFN- $\mathrm{y}(\mathrm{pg} / \mathrm{ml})(\mathrm{D})$ levels before anti-TB therapy in Thai patients with HIV/TB coinfection and TB in comparison with healthy controls $(\mathrm{HC}), \mathrm{HIV}+\mathrm{HAART}$ - and HIV+HAART+. Each dot represented one individual. A horizontal bar indicated the median of each group. *, $p<0.05 ; * *, p<0.01$.

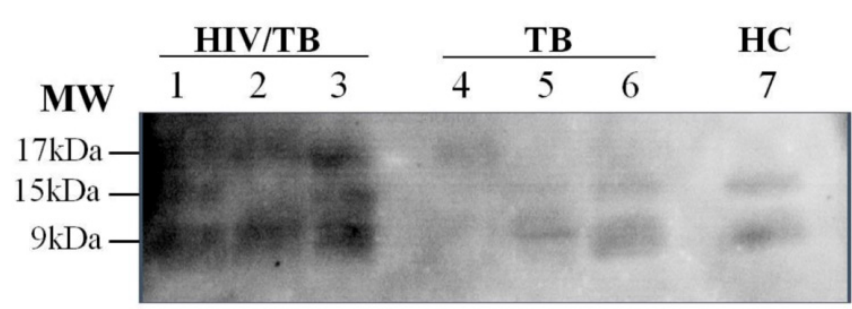

Fig 2. Isoforms of granulysin expression in plasma from Thai patients by Western blot analysis. Lane I-3, HIV/TB coinfection plasma, 3 bands of $\sim$ I7kDa, I5kDa and 9kDa isoforms; Lanes: 4-6, TB plasma, I band of $\sim 17 \mathrm{kDa}$ isoform (Lane 4) and 2 bands of $\sim 15 \mathrm{kDa}$ and 9kDa isoforms (Lane 5-6); Lane 7, 2 bands of $\mathrm{HC} \sim 15 \mathrm{kDa}$ and $9 \mathrm{kDa}$ isoforms. 


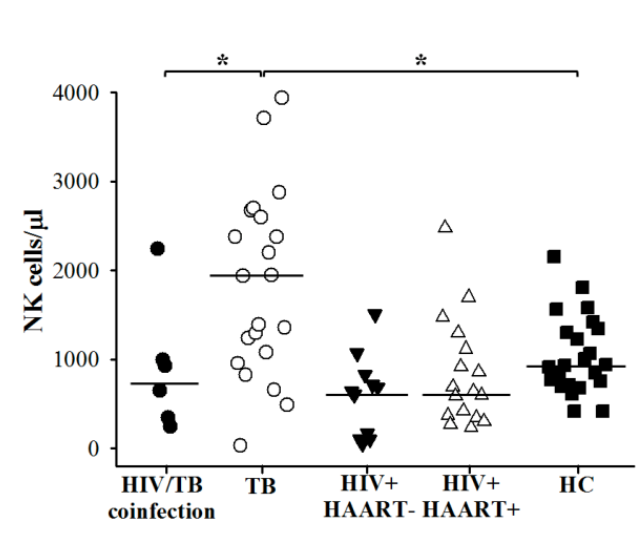

A

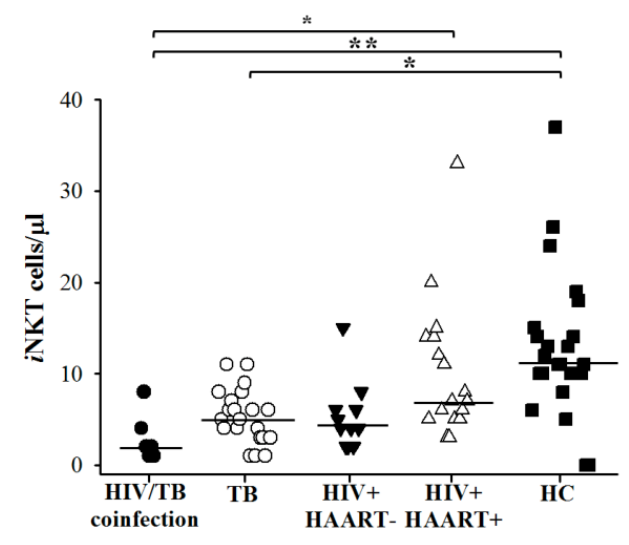

B

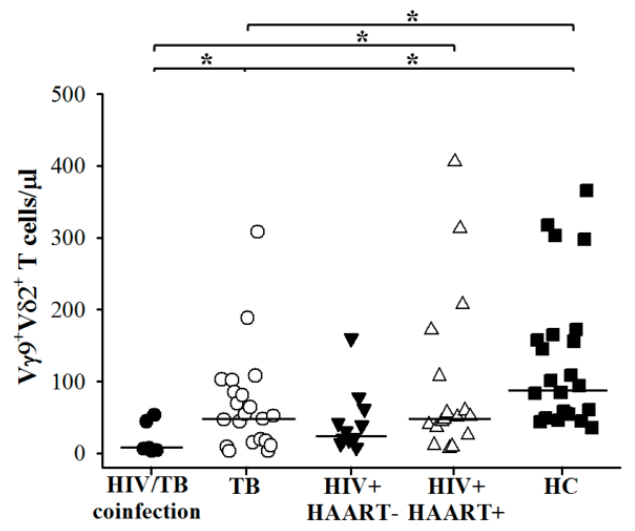

C

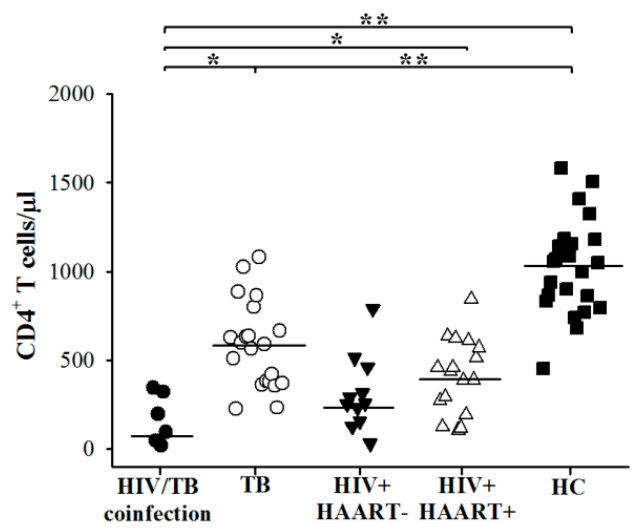

D

$\mathbf{E}$

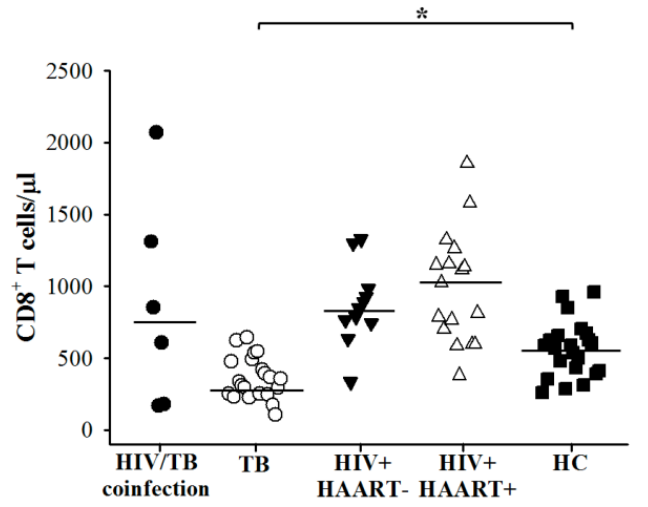

Fig 3. The number of NK cells (A), iNKT cells $(B), \vee y 9^{+} \vee \delta 2^{+} T$ cells $(C), C D 4^{+} T$ cells $(D)$ and $C D 8^{+} T$ cells $(E)$ per microliter $(\mu l)$ in Thai patients with HIV/TB coinfection and TB in comparison with healthy controls (HC), HIV+HAART- and HIV+HAART+ determined by flow cytometric analysis. Each dot represented one individual. A horizontal bar indicated the median of each group. *, $p<0.05 ; * *, p<0.0$ I.

Relatively smaller number of $i$ NKT cells (median $=2$ cells $/ \mu \mathrm{l}$, ranged $1-5)$ and $\mathrm{CD} 4^{+} \mathrm{T}$ cells (median $=$ 146 cells/ $\mu \mathrm{l}$, ranged 39-327) were found in HIV/TB than TB patients (median of $i \mathrm{NKT}$ cells $=5$ cells $/ \mu \mathrm{l}$, ranged 3-7, $\mathrm{p}=0.029 ;$ median of $\mathrm{CD}^{+} \mathrm{T}$ cells $=589$ cells $/ \mu \mathrm{l}$, ranged 375-732, $\mathrm{p}=0.001) . \mathrm{V}_{\gamma} 9^{+} \mathrm{V} \delta 2^{+} \mathrm{T}$ cells in HIV $/ \mathrm{TB}$ coinfection (median $=7$ cells $/ \mu \mathrm{l}$, ranged
6-46) also tended to be lower than those in TB (median $=52$ cells $/ \mu \mathrm{l}$, ranged 16-94), although it was not significantly different. In addition, small number of $\mathrm{CD}^{+} \mathrm{T}$ cells was remarkable in $\mathrm{TB}$ (median $=339$ cells/ $\mu \mathrm{l}$, ranged 249-485), whereas the $\mathrm{CD}^{+} \mathrm{T}$ cells in HIV/TB coinfection were kept high in circulation (median $=730$ cells $/ \mu 1$, ranged 178-1499). 
NK cells, $C D 8^{+} T$ cells, granulysin, perforin and IFN-Y in patients with HIV/TB coinfection and TB

The number of $\mathrm{NK}, i \mathrm{NKT}, \mathrm{V} 9^{+} \mathrm{V} \delta 2^{+} \mathrm{T}, \mathrm{CD}^{+} \mathrm{T}$ and $\mathrm{CD}^{+} \mathrm{T}$ cells were correlated with granulysin, perforin, granzyme-B and IFN- $\gamma$ levels at the time of enrollment. In HIV/TB patients, NK cells and CD8+ T cells were not significantly correlated with granulysin, but both cell types positively correlated with perforin $(\mathrm{p}=0.045, \mathrm{r}=0.714$ and $\mathrm{p}=0.036, \mathrm{r}=0.771$, respectively). In TB patients, NK cells showed negative correlation, whereas $\mathrm{CD} 8^{+} \mathrm{T}$ cells was positively correlated with granulysin $(\mathrm{p}=0.011, \mathrm{r}=-0.499), \mathrm{p}=$ $0.049, \mathrm{r}=0.398$, respectively). For IFN- $\gamma$, a trend to increase in relation to the numbers of NK cells in patients with both HIV/TB coinfection and TB were seen. For the rest, no significant correlations were found among effector molecules and cell populations.

\section{Increased circulating granulysin and decreased IFN- $\gamma$ levels in HIV/TB coinfection and TB after completion of anti-TB therapy}

After 6-9 months of anti-TB therapy, only 3 HIV/TB patients and 13 TB patients could be followed-up when they were considered as treatment success (Figure 4). In patients with HIV/TB coinfection, the granulysin levels after completion of anti-TB therapy $($ median $=8.535 \mathrm{ng} / \mathrm{ml}$ ) showed a trend to

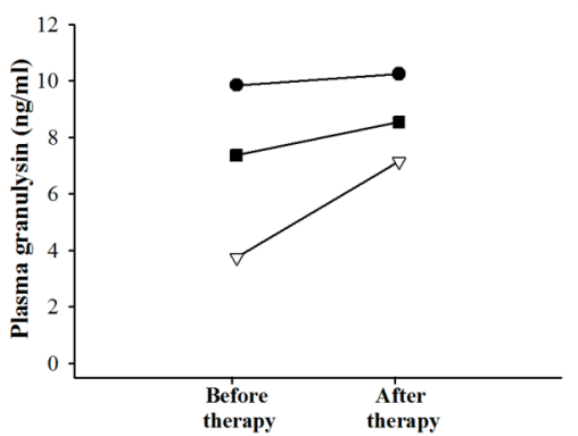

A

C

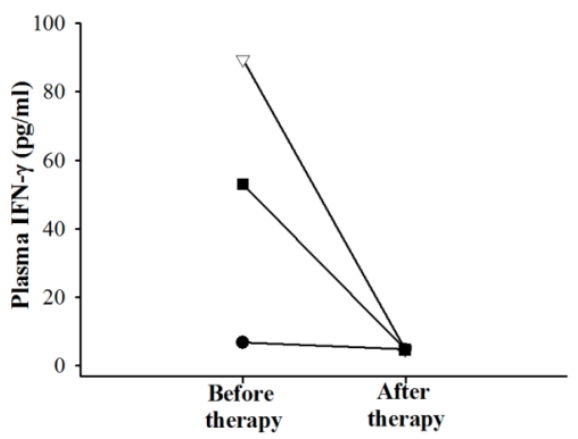

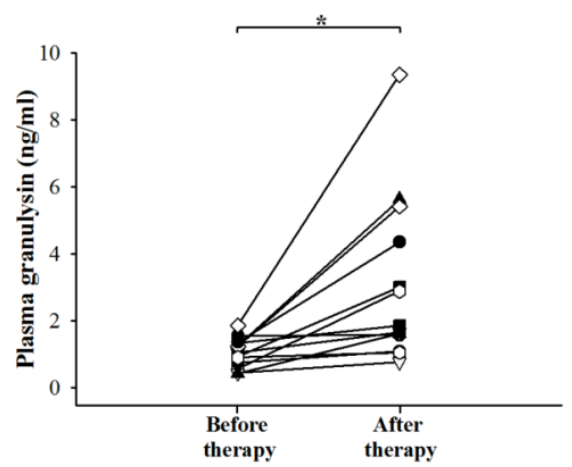

increase compared to those before therapy (median $=$ $7.365 \mathrm{ng} / \mathrm{ml})(\mathrm{p}=0.208)$, although significant difference was not found (Figure 4A). Whereas in TB patients, the granulysin levels after completion of anti-TB therapy (median $=1.861 \mathrm{ng} / \mathrm{ml}$ ) were significantly higher than those before therapy (median = $1.048 \mathrm{ng} / \mathrm{ml})(\mathrm{p}=0.002)$ (Figure 4B).

In contrast, the IFN- $\gamma$ levels after completion of anti-TB therapy were significantly lower in HIV/TB (median $<4.7 \mathrm{pg} / \mathrm{ml}$ ) (Figure $4 \mathrm{C}$ ) and $\mathrm{TB}$ patients (median $<4.7 \mathrm{pg} / \mathrm{ml}$ ) (Figure 4D) than those before therapy (median $=53.04 \mathrm{pg} / \mathrm{ml}$ for $\mathrm{HIV} / \mathrm{TB}, \mathrm{p}=0.037$ and $10.04 \mathrm{pg} / \mathrm{ml}$ for $\mathrm{TB}, \mathrm{p}=0.012$ ).

\section{Clinical profiles in relation to effector mole- cules and cells in patients with HIV/TB coin- fection}

Among $6 \mathrm{HIV} / \mathrm{TB}$ patients, 4 were considered as cured, whereas 2 could not be followed-up (Table 1). Among these, 3 patients with cured after 6-8 months of $\mathrm{TB}$ treatment had high granulysin and perforin levels and high number of NK cells (Table 2). Obviously, they had very high $\mathrm{CD} 8^{+} \mathrm{T}$ cells. While one patient with cured after 18 months of TB treatment had quite low $\mathrm{CD}^{+} \mathrm{T}$ cells, but high NK cells and even very high IFN-Y levels, but the granulysin and perforin levels were lower than other 3 patients.

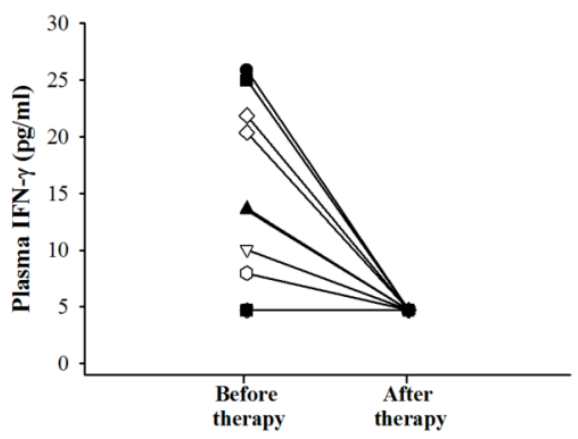

Fig 4. Circulating granulysin $(\mathrm{ng} / \mathrm{ml})$ and IFN-Y $(\mathrm{pg} / \mathrm{ml})$ in Thai patients with HIV/TB coinfection $(A$ and $C)$ and patients with TB (B and D) before and after completion of anti-TB therapy. Each dot represented one individual. *, $p<0.05$. 


\section{Discussion}

In this study, circulating granulysin and other immune molecules, perforin, granzyme-B and IFN- $\gamma$ in relation to the numbers of NK cells, $i \mathrm{NKT}$ cells, $\mathrm{V} 9^{+} \mathrm{V} \delta 2^{+} \mathrm{T}$ cells, $\mathrm{CD} 4^{+} \mathrm{T}$ and $\mathrm{CD} 8^{+} \mathrm{T}$ cells in $\mathrm{HIV} / \mathrm{TB}$ coinfection, TB and other control groups before and after completion of anti-TB therapy were investigated. Before anti-TB therapy, the extremely higher granulysin in HIV/TB coinfection and slightly lower granulysin in active pulmonary $\mathrm{TB}$ than $\mathrm{HC}$ were noted, and both increased after completion of anti-TB therapy, presumably indicating its protective role of host defense against $M t b$ infection. Low granulysin levels in active TB, may be explained by rapid consumption due to ongoing effector immune response, or reduced during active disease due to the reduction of $\mathrm{T}$ cell subsets dedicated to its production $[12,25]$. Interestingly, the results of higher granulysin and perforin levels, higher number of NK cells and obviously higher number of $\mathrm{CD}^{+} \mathrm{T}$ cells in $\mathrm{HIV} / \mathrm{TB}$ coinfection with cured after 6-8 months of TB treatment than the one with cured after 18 months upon therapy, indicated the effective role of NK cells in innate and $\mathrm{CD}^{+} \mathrm{T}$ cells in adaptive immunity. However, the patient with 18 months cured had high NK cells and obviously high IFN- $\gamma$ levels suggesting the effective role in innate immunity. These results in Thai patients with HIV/TB coinfection were in accordance with the findings in Japanese patients with HIV/TB coinfection which also showed the higher plasma granulysin levels (median $=15.222 \mathrm{ng} / \mathrm{ml}$, ranged 11.372-19.946, $\mathrm{n}=19$ ) than healthy individuals $($ median $=4.869 \mathrm{ng} / \mathrm{ml}$, ranged 2.262-9.983, $\mathrm{n}=19$ ) (Figure 5) (Data provided by Dr. Shinichi Oka and his colleagues, AIDS Clinical Center, National Center for Global Health and Medicine, Tokyo, Japan on November $1^{\text {st }}$, 2012). The explanation of the high granulysin in HIV/TB coinfection might be possibly due to (i) exposure to many antigens or with complication occurrences once those patients were concurrently infected with both pathogens as chronic infection which may influence quite high granulysin levels or (ii) the results of immune activation in HIV/TB coinfection or (iii) high number of $\mathrm{CD} 8^{+} \mathrm{T}$ cells may play a major cell for granulysin production.

In this study, three bands with $\sim 17 \mathrm{kDa}, 15 \mathrm{kDa}$ and $9 \mathrm{kDa}$ were identified in plasma from $\mathrm{HIV} / \mathrm{TB}$ coinfected patients. Though $9 \mathrm{kDa}$ form of granulysin is cleaved from $15 \mathrm{kDa}$ precursor by protease, it is known that $9 \mathrm{kDa}$ form cannot be detected in normal plasma [10]. It is assumed that $\sim 17 \mathrm{kDa}$ band may correspond to full length granulysin with signal sequence. Release of granulysin with signal peptide is questionable, except that from disrupted cells due to necrosis. So far, this is the first demonstration of granulysin in patients with HIV/TB coinfection using DS method to concentrate peptides and low molecular weight proteins in plasma.

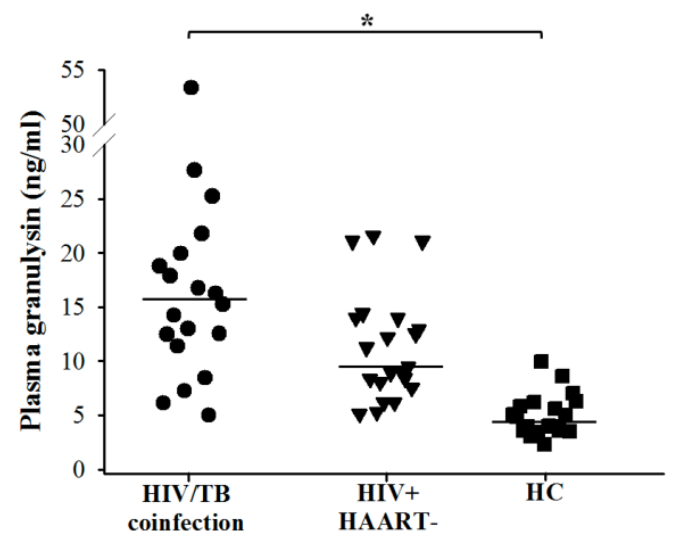

Fig 5. Circulating granulysin $(\mathrm{ng} / \mathrm{ml})$ in Japanese patients with HIV/TB coinfection before anti-TB therapy, HIV+HAART- and healthy controls (HC). Each dot represented one individual. A horizontal bar indicated the median of each group. *, $p<0.05$.

High levels of granulysin coexisted with relatively large number of $\mathrm{CD}^{+} \mathrm{T}$ cells, but not proportional to $i \mathrm{NKT}, \mathrm{V} 9^{+} \mathrm{V} \delta 2^{+} \mathrm{T}, \mathrm{CD} 4^{+} \mathrm{T}$ cells and NK cells in patients with HIV/TB coinfection in this study. In fact, the decreased $\mathrm{CD}^{+} \mathrm{T}$ cells in patients with HIV/TB coinfection were previously shown to be associated with failure of granuloma formation to contain $M t b$ infection, thereby causing mycobacterial dissemination [28]. Furthermore, activation of HIV-1 by $M t b$ components may be particularly important in viral expansion at the times when $M t b$ growth becomes exponential, and TB overwhelms host defenses [29]. Compared to HIV/TB coinfection, the significantly decreased $i \mathrm{NKT}, \mathrm{V}_{\gamma} 9^{+} \mathrm{V} \delta 2^{+} \mathrm{T}$ cells, $\mathrm{CD} 4^{+} \mathrm{T}$ cells, $\mathrm{CD}^{+} \mathrm{T}$ cells and increased NK cells in patients with TB before anti-TB therapy indicated the possibility that granulysin may be compromised by $\mathrm{T}$ cell subset with significantly correlated with $\mathrm{CD}^{+} \mathrm{T}$ cells. Obviously, increased NK cells were correlated with decreased granulysin, suggesting that it may not be released from NK cells, or granulysin inside the cells does not degranulated later upon activation. However, it could not be assured that (i) how much granulysin contained intracellularly and released to extracellular space since only free granulysin in circulation was measured in this study, (ii) how frequent expression of granulysin was induced in accumulated immune cells including CD8 ${ }^{+} \mathrm{T}$ cells at the TB-affected 
sites, particularly in patients with HIV/TB coinfection, (iii) the exact duration of being infected with $M t b$ until development to active disease with sputum AFB positive, (iv) how much granulysin was released in latent and early stage of active $\mathrm{TB}$, and (v) varied granulysin levels may depend upon the nutrition and health status in individuals. Similarly, low perforin in TB were seen. The persistence of clinical disease was evidenced to be associated with deficient expression of perforin and granulysin at the local site of TB infection [18]. Although significant infiltration of $\mathrm{CD}^{+}$ and $\mathrm{CD}^{+} \mathrm{T}$ cells was evidenced in TB lesions in patients with persistent inflammation [18], however, the levels of either perforin or granulysin remained low in TB lesions including severely impaired expression of these cytolytic effector molecules inside the distinct granules [18]. In the present study, either NK cells or $\mathrm{CD}^{+} \mathrm{T}$ cells were significantly correlated with the elevation of perforin in patients with HIV/TB coinfection but not in TB, indicating their potential functions in HIV/TB coinfection, as previously shown in individuals chronically infected with HIV-1 who have increased extracellular perforin levels compared with uninfected individuals, while the impaired functional activity of CTLs and NK cells during HIV-1 infection has been attributed to the decreased intracellular levels of perforin and granzyme B [30]. It is suggested that the induction of perforin has a distinct pathway from that of granulysin in HIV/TB coinfection in this study. However, in TB, no differences in granzyme B levels were found which is supported by similar results in slow or fast TB responders upon TB treatment at any time points and healthy individuals with PPD positive [31].

In contrast to granulysin, perforin and granzyme-B, the elevated circulating IFN- $\gamma$ seen in patients with both HIV/TB coinfection and TB before anti-TB therapy which decreased after completion of therapy inferred a role of IFN- $\gamma$ in effective immunity against $M t b$ infection. The results were similar to the previous report on significantly higher plasma IFN- $\gamma$ levels in patients with active pulmonary TB than healthy individuals which decreased after treatment, suggesting that the levels may result from local production and spill-over of IFN- $\gamma$ from activated lymphocytes sequestered at the site of $M t b$ infection [22, $24,32]$. In human and mouse models, IFN- $\gamma$ is evidenced to be normally synthesized from $\mathrm{CD}^{+} \mathrm{T}$ cells activated upon recognition of $M t b$ antigen on antigen presenting cells [22] as well as by $M t b$ antigens specific $\mathrm{CD}^{+} \mathrm{T}$ cells [33]. Although IFN- $\gamma$ producing $\mathrm{CD}^{+} \mathrm{T}$ cells of Th1 type is of major importance, however, other $\mathrm{T}$ cells notably $\mathrm{CD} 8^{+} \mathrm{T}$ cells and perhaps $\gamma \delta \mathrm{T}$ cells or CD1-restricted T cells participate in immune function as well [34]. However, increased $\mathrm{CD}^{+}$and decreased CD8 ${ }^{+} \mathrm{T}$ cells in TB in this study conversed to HIV/TB coinfection. Elevated IFN- $\gamma$ levels in HIV/TB coinfection might be possibly due to the persistence of immune activation and chronically HIV associated TB. In addition, $M t b$ infection may support the HIV-1 replication and dissemination through dysregulation of host cytokines, chemokines and their receptors [29]. HIV/TB coinfection could inhibit cell mediated responses to $M t b$ through interruption of IL-2 signaling as well [35]. The deleterious effects of HIV infection in $\mathrm{CD}^{+}{ }^{+} \mathrm{T}$ cells impair immune function as resulting in a failure to contain mycobacterial infection and restrict the replication of the microbe [36].

In this study, IFN- $\gamma$ had a trend to increase along with NK cells in patients with both HIV/TB coinfection and $\mathrm{TB}$, suggesting the possible production of IFN- $\gamma$ from NK cells during initiation against $M t b$ infection which high NK cells were shown. It is also possible as recently shown that NK cells secrete IFN- $\gamma$ which stimulates monocytes to produce IL-15 and IL-18, which in turn facilitates expansion of $\mathrm{CD}^{+} \mathrm{T}$ cells producing IFN- $\gamma$ in response to $M t b$-infected monocytes [37]. Since NK cells produce IFN- $\gamma$ in early $M t b$ infection [38], therefore, this pathway is likely to be important in facilitating expansion of $\mathrm{CD}^{+} \mathrm{T}$ cells during immune response to $M t b$ in vivo [37].

In conclusion, the alteration of circulating granulysin, perforin and IFN- $\gamma$ has potential function in host immune response in TB and HIV/TB coinfection. Circulating granulysin and perforin levels in TB were lower than healthy controls, whereas the granulysin levels in HIV/TB coinfection were much higher than in any other disease groups. Increased granulysin and decreased IFN- $\gamma$ levels in HIV/TB coinfection and TB after completion of anti-TB therapy were noted. Slightly high perforin levels in HIV/TB coinfection indicated the immune activation in TB associated with HIV infection. Three distinct isoforms with $\sim 17 \mathrm{kDa}$, $15 \mathrm{kDa}$ and $9 \mathrm{kDa}$ of granulysin were recognized in plasma of HIV/TB coinfection. The number of CD8 ${ }^{+} \mathrm{T}$ cells kept high but NK cells and other possible cellular sources of granulysin were decreased in HIV/TB coinfection, which in contrast to what seen in TB in which low $\mathrm{CD}^{+} \mathrm{T}$ cells but high NK cells were found, suggesting their different sources of granulysin, which in turn, play a crucial role in host defense against tuberculosis and in association with HIV infection. This is the first demonstration so far of granulysin in HIV/TB coinfection.

\section{Acknowledgements}

The authors wish to thank the patients from 
Chiang Rai Hospital and Mae Chan Hospital for their kind participation in the study and the staffs of TB/HIV Research Project, the collaborative research project under Research Institute of Tuberculosis (RIT), Japan Anti-Tuberculosis Association (JATA) and Ministry of Public Health of Thailand for blood collection and providing clinical data. This study was supported by the Royal Golden Jubilee Ph.D. Program of the Thailand Research Fund (Grant No. PHD/0227/2549); Faculty of Tropical Medicine, Mahidol University; Health and Labour Science Research Grants for Research on Emerging and Re-emerging Infectious Diseases (H17-shinko-021 and H20-shinko-014), Ministry of Health, Labour and Welfare, Japan; and Global Health and Medicine (17C-1 and 20C-3), Ministry of Health, Labour and Welfare, Japan.

\section{Abbreviations}

CFP: culture filtrate protein; CTL: cytotoxic T lymphocyte; ELISA: enzyme-linked immunosorbent assay; ESAT: early secreted antigenic target; HAART: highly active antiretroviral therapy; HIV: human immunodeficiency virus; IFN- $\gamma$ : interferon gamma; IL: interleukin; $i \mathrm{NKT}$ : invariant NKT; MDR: multi-drugs resistance; Mtb: Mycobacterium tuberculosis; NK: natural killer; PBMCs: peripheral blood mononuclear cells; TB: tuberculosis; Th1: T-helper type 1; TLR: toll-like receptor; TNF: tumor necrosis factor; XDR: extensively drugs resistance

\section{Competing Interests}

The authors have declared that no competing interest exists.

\section{References}

1. [Internet] WHO: Geneva, Switzerland. Global Tuberculosis report 2012. http://www.who.int/tb/publications/global_report/en/

2. Whalen C, Horsburgh CR, Hom D, Lahart C, Simberkoff M, Ellner J. Accelerated course of human immunodeficiency virus infection after tuberculosis. Am J Respir Crit Care Med. 1995; 151: 129-35.

3. Goletti D, Weissman D, Jackson RW, et al. Effect of Mycobacterium tuberculosis on HIV replication: role of immune activation. J Immunol. 1996; 157: 1271-8

4. Hazenberg MD, Hamann D, Schuitemaker H, Miedema F. T cell depletion in HIV-1 infection: How CD4 ${ }^{+}$T cells go out of stock. Nat Immunol. 2000; 1: 285-289.

5. Dietrich CR, Flynn JL. HIV-1/Mycobacterium tuberculosis Coinfection Immunology: How Does HIV-1 Exacerbate Tuberculosis? Infect Immun. 2011; 79: 1407-17.

6. Pena SV, Hanson DA, Carr BA, Goralski TJ, Krensky AM. Processing, subcellular localization and function of 519 (granulysin), a human late T cell activation molecule with homology to small, lytic, granule proteins. J Immunol. 1997; 158: 2680-8.

7. Krensky AM, Clayberger C. Biology and clinical relevance of granulysin. Tissue Antigens. 2009; 73: 193-8.

8. Hanson DA, Kaspar AA, Poulain FR, Krensky AM. Biosynthesis of granulysin, a novel cytolytic molecule. Mol Immunol. 1999; 36: 413-22.

9. Stenger S, Hanson DA, Teitelbaum R, et al. An antimicrobial activity of cytolytic T cells mediated by granulysin. Science. 1998; 282: 121-5.
10. Ogawa K, Takamori $Y$, Suzuki K, et al. Granulysin in human serum as a marker of cell mediated immunity. Eur J Immunol. 2003; 33: 1925-33.

11. Pena SV, Krensky AM. Granulysin, a new human cytolytic granule-associated protein with possible involvement in cell mediated cytotoxicity. Semin Immunol. 1997; 9: 117-25.

12. Sahiratmadja E, Alisjahbana B, Buccheri S, et al. Plasma granulysin levels and cellular interferon- $\gamma$ production correlate with curative host responses in tuberculosis, while plasma interferon- $\gamma$ levels correlate with tuberculosis disease activity in adults. Tuberculosis. 2007; 87: 312-21.

13. Serbina NV, Lazarevic V, Flynn JL. CD4 ${ }^{+} \mathrm{T}$ cells are required for the development of cytotoxic CD8 ${ }^{+} \mathrm{T}$ cells during Mycobacterium tuberculosis infection. J Immunol. 2001; 167: 6911-7000.

14. Gansert JL, Kiessler V, Engele M, et al. Human NKT cells express granulysin and exhibit antimycobacterial activity. J Immunol. 2003; 170: 3154-61.

15. Mueller H, Fae' KC, Magdorf $\mathrm{K}$, et al. Granulysin-expressing CD4 ${ }^{+} \mathrm{T}$ cells as candidate immune marker for tuberculosis during childhood and adolescence. PLoS One. 2011; 6: e29367. doi:10.1371/journal.pone.0029367

16. Montoya CJ, Cataño JC, Ramirez Z, Rugeles MT, Wilson SB, Landay AL. Invariant NKT cells from HIV-1 or Mycobacterium tuberculosis-infected patients express an activated phenotype. Clin Immunol. 2008; 127: 1-6.

17. 17. Dieli F, Troye-Blomberg M, Ivanyi J, et al. Granulysin-dependent killing of intracellular and extracellular Mycobacterium tuberculosis by Vy9/V82 T lymphocytes. J Infect Dis. 2001; 184: 1082-5.

18. Andersson J, Samarina A, Fink J, Rahman S, Grundstro S. Impaired expression of perforin and granulysin in $\mathrm{CD}^{+} \mathrm{T}$ cells at the site of infection in human chronic pulmonary tuberculosis. Infect Immun. 2007; 75: 5210-22.

19. Flynn JL, Chan J. Immunology of tuberculosis. Annu Rev Immunol. 2001; 19: 93-129.

20. Hammond AS, McConkey SJ, Hill PC, et al. Mycobacterial T cell responses in HIV-infected patients with advanced immunosuppression. J Infect Dis. 2008; 197: 295-9.

21. Geldmacher C, Schuetz A, Ngwenyama N, et al. Early Depletion of Mycobacterium tuberculosis-Specific T Helper 1 Cell Responses after HIV-1 Infection. J Infect Dis. 2008; 198: 1590-8.

22. Deveci F, Akbulut H, Turgut T, Muz MH. Changes in serum cytokine levels in active tuberculosis with treatment. Mediators Inflamm. 2005; 5: 256-62.

23. He XY, Xiao L, Chen HB, et al. T regulatory cells and Th1/Th2 cytokines in peripheral blood from tuberculosis patients. Eur J Clin Microbiol Infect Dis. 2010; 29: 643-50.

24. Di Liberto D, Buccheri S, Caccamo N, et al. Decreased serum granulysin levels in childhood tuberculosis which reverses after therapy. Tuberculosis. 2007; 87: 322-8.

25. Pitabut N, Mahasirimongkol S, Yanai H, et al. Decreased plasma granulysin and increased interferon-gamma concentrations in patients with newly diagnosed and relapsed tuberculosis. Microbiol Immunol. 2011; 55: 565-73.

26. Subramanyam S, Hanna LE, Venkatesan P, Sankaran K, Narayanan PR, Swaminathan S. HIV alters plasma and $M t b$-induced cytokine production in patients with tuberculosis. J Interferon Cytokine Res. 2004; 24: 101-6.

27. Kawashima Y, Fukutomi T, Tomonaga $\mathrm{T}$, et al. High-yield peptide-extraction method for the discovery of subnanomolar biomarkers from small serum samples. J Prot Res. 2010; 9: 1694-705.

28. Corbett EL, Watt CJ, Walker N, et al. The growing burden of tuberculosis: global trends and interactions with the HIV epidemic. Arch Intern Med. 2003; 163: 1009-21.

29. Toosi Z, Wu M, Islam N, Teixeira-Johnson L, Hejal R, Aung H. Transactivation of human immunodeficiency virus-1 in T-cells by Mycobacterium tuberculosis-infected mononuclear phagocytes. J Lab Clin Med. 2004; 144: 108-15.

30. Klingstrom J, Gudmundsdotter L, Zuber B, et al. Elevated levels of serum perforin in chronic HIV-1 and acute SIV/SHIV infection. AIDS. 2006; 20: 119-32.

31. Siawaya JFD, Bapela NB, Ronacher K, et al. Immune parameters as markers of tuberculosis extent of disease and early prediction of anti-tuberculosis chemotherapy response. J Infect. 2008; 56: 340-7.

32. Dlugovitzky D, Torres-Morales A, Rateni L, et al. Circulating profile of Th1 and Th2 cytokines in tuberculosis patients with different degrees of pulmonary involvement. FEMS Immunol Med Microbiol. 1997; 18: 203-7.

33. Serbina NV, Flynn J. Early emergence of $\mathrm{CD}^{+} \mathrm{T}$ cells primed for production of Type 1 cytokines in the lungs of Mycobacterium tuberculosis-infected mice. Infect Immun. 1999; 67: 980-8. 
34. Schaible UE, Collins HL, Kaufmann SH. Confrontation between intracellular bacteria and the immune system. Adv Immunol. 1999; 71: 267-77.

35. Lawn SD, Bekker LG, Miller RF. Immune reconstitution disease associated with mycobacterial infections in HIV-infected individuals receiving antiretrovirals. Lancet Infect Dis. 2005; 5: 361-73.

36. Lawn SD. Tuberculosis and HIV co-infection. Medicine. 2005; 33: 112-3.

37. Vankayalapati R, Klucar P, Wizel B, et al. NK cells regulate CD8 ${ }^{+} \mathrm{T}$ cell effector function in response to an intracellular pathogen. J Immunol. 2004; 172: 130-7.

38. Junqueira-Kipnis AP, Kipnis A, Jamieson A, et al. NK cells respond to pulmonary infection with Mycobacterium tuberculosis, but play a minimal role in protection. J Immunol. 2003; 171: 6039-45. 